\title{
Pengurangan Subsidi Pupuk dan Kenaikan Tingkat Suku Bunga terhadap Kesejahteraan Petani Lada Indonesia
}

\author{
MUHAMMAD RIZAL TAUFIKURAHMAN ${ }^{1}$ \\ LA DIADHAN HUKAMA ${ }^{2}$ \\ ${ }^{1}$ Program Pascasarjana Institut Pertanian Bogor \\ ${ }^{2}$ Fakultas Ekonomi Universitas YARSI
}

\begin{abstract}
Fertilizer Price Subsidy Reduction and Increase in Interest Rates Pepper Farmers Welfare in Indonesia, This aims of this study are to explain the influence of price subsidy reduction of fertilizer and to measure the impact of increasing interest rates for farmers welfare in Indonesia by using the model of simultaneous equations system estimation model with the condition of each equation is identified excessive, then the parameter estimation method was used Two Stage Least Squares (2 SLS). Based on the analysis results show the model prediction coefficient of determination (R2) ranged from 52\% to 98\%. This shows the diversity of each endogenous variable can be explained quite well by the explanatory variables in each structural equation. Explanatory variables in each equation are jointly significant enough to explain the diversity of endogenous variables, which is shown from the statistical value of $F$ ranges between 2.678 to 172.427.
\end{abstract}

Keywords: fertilizer subsidy, interest rate, white pepper, welfare farmer

\begin{abstract}
Abstrak
Penelitian ini bertujuan untuk menjelaskan pengaruh Pengurangan Subsidi Harga Pupuk dan Kenaikan Suku Bunga Kesejahteraan Petani Lada di Indonesia dengan menggunakan model pendugaan model sistem persamaan simultan dengan kondisi setiap persamaannya yang teridentifikasi berlebih, maka pendugaan parameternya dilakukan dengan metode Two Stage Least Squares (2 SLS). Berdasarkan hasil analisis hasil pendugaan model menunjukkan koefisien determinasi $\left(\mathrm{R}^{2}\right)$ berkisar antara 52\% sampai 98\%. Hal ini menunjukkan keragaman masing-masing peubah endogen dapat dijelaskan cukup baik oleh peubah-peubah penjelas pada masing-masing persamaan struktural. Peubah-peubah penjelas pada setiap persamaan secara bersama-sama cukup nyata menjelaskan keragaman peubah endogen, yang ditunjukkan dari nilai statistik F berkisar antara 2.678 hingga 172.427.
\end{abstract}

Kata kunci: subsidi pupuk, suku bunga, lada putih, kesejahteraan petani

\footnotetext{
${ }^{2}$ Penulis Korespondensi: YARSI TOWER, Lantai 4, Jl. Letjen. Suprapto, Cempaka Putih, Jakarta 10510

Telp/Fax.+62 21 4269289, Email: adhanh@yahoo.com
} 


\section{PENDAHULUAN}

Sub sektor perkebunan memiliki komoditi andalan yang berperan sebagai penghasil devisa, dan bahan baku industri dalam negeri. Menurut data tahun 1993, komoditi lada menyumbang devisa negara sebesar US\$ 43.635 juta $(1,96 \%)$ dan merupakan penyumbang devisa terbesar keenam setelah komoditi karet $(47,89 \%)$, minyak sawit $(21,27 \%)$, kopi $(14,41 \%)$, teh $(7,01 \%)$, dan coklat $(7,46 \%)$. Sampai saat ini Indonesia masih merupakan negara produsen dan pengekspor lada putih terbesar di dunia Namun demikian nilai ekspor komoditi lada dari tahun ke tahun cenderung mengalami peningkatan. Menurut data IPC (1998), bahwa total nilai ekspor lada Indonesia menjadi US\$ 184.843 juta atau mengalami peningkatan lebih dari empat kali lipat dibandingkan tahun 1993. Apabila dilihat dari sisi tenaga kerja, komoditi ini menyerap lebih dari 500.000 orang petani. Sedangkan sebagai bahan baku industri dalam negeri, lada digunakan untuk industri makanan, obat-obatan dan kosmetika.

Pada umumnya komoditi ini diusahakan oleh perkebunan rakyat, yaitu sebesar $99,83 \%$ dan sisanya diusahakan oleh perkebunan swasta. Jenis perkebunan rakyat umumnya dicirikan oleh usaha tani tradisional, dimana pengelolaannya hampir sepenuhnya tergantung pada kondisi dan kebaikan alam. Meskipun pemerintah telah melakukan pembinaan terhadap petani lada dalam rangka meningkatkan produksi nasional, tenyata sulit untuk dicapai penigkatan produksi.

Selanjutnya, peningkatan produksi lada putih Indonesia selama kurun waktu lima tahun terakhir (1998-2003) ternyata tidak diikuti oleh perkembangan ekspor lada putih yang menggembirakan. Perkembangan ini nampaknya berkaitan erat dengan kondisi pasar lada putih dunia yang tidak stabil, ditandai dengan fluktuasi harga dan volume perdagangan lada putih yang cukup besar. Mengingat lebih dari $80 \%$ produksi lada putih dipasarkan ke luar negeri, maka ketidakstabilan pasar lada putih dunia tersebut akan mempengaruhi perekonomian lada putih domestik.

Permasalahan lain yang dihadapi dalam perekonomian lada putih adalah fluktuasi harga yang besar, baik di pasar dunia maupun domestik. Kondisi ini dapat terjadi karena beberapa hal, antara lain faktor produksi, mutu, serta faktor penawaran dan permintaan di pasar dunia.
Fluktuasi harga yang terjadi di pasar dunia akan berdampak pula terhadap harga lada putih ditingkat eksportir, importir, dan petani domestik. Selain itu, perekonomian lada putih Indonesia tidak terlepas dari pengaruh kebijakan dan faktor ekonomi eksternal, seperti tingkat suku bunga, tingkat upah, serta nilai tukar rupiah terhadap dollar Amerika, produksi lada dan permintaan impor.

Pada pasar produk dan pasar masukan yang bersaing sempurna, fungsi penawaran mencerminkan kuantitas produk yang ditawarkan sebagai fungsi dari harga produk dan harga masukan. Suatu fungsi penawaran perusahaan yang memaksimumkan keuntungan dapat diturunkan dari fungsi keuntungan yang dicapai melalui dua syarat, yaitu syarat orde satu (first order condition) dan syarat orde dua (second order condition). Menurut syarat pertama, fungsi keuntungan akan maksimum jika turunan pertama dari fungsi tersebut sama dengan nol, berarti nilai produk marginal masing-masing faktor harus sama dengan harga masing-masing faktor yang digunakan. Syarat kedua terpenuhi jika turunan kedua dari fungsi tersebut lebih kecil dari nol atau jika Hessian Determinant lebih besar dari nol, berarti fungsi produksi cembung ke arah titik origin (Beattle \& Taylor, 1995, Henderson and Quandt, 1980, Koutsoyiannis, 1975).

Artikel ini bertujuan untuk mencari faktorfaktor apa saja yang berperan dalam mempengaruhi produksi lada putih Indonesia dan seberapa besar pengaruh dari masing-masing faktor tersebut. Kedua, ingin diselidiki faktorfaktor apa saja yang menentukan harga lada putih, baik di tingkat dunia, eksportir, dan petani domestik dan terkahir menentukan bagaimana dampak yang timbul akibat adanya perubahan kebijakan dan faktor-faktor tersebut terhadap penawaran ekspor lada putih nasional. Berdasarkan masalah dan tujuan yang telah dikemukakan, maka penelitian ini pada dasarnya akan menggunakan pendekatan (1) Produksi Lada Putih, (2) Penawaran ekspor dan Permintaan Impor Lada Putih, (3) Keterkaitan antara harga lada putih dunia dengan harga di tingkat eksportir, importir, dan petani domestik, dan (4) konsep elastisitas, guna mengetahui tingkat responsif suatu peubah endogen tertentu terhadap perubahan peubah eksplanatorinya. 


\section{METODE}

\section{Kerangka Pemikiran}

\section{a. Fungsi Produksi Lada Putih}

Materi pokok teori produksi bertumpu pada fungsi produksi, yaitu suatu fungsi yang menggambarkan hubungan teknis antara masukan produksi (input) dan hasil produksinya (output). Fungsi produksi dapat menggambarkan teknologi yang digunakan oleh suatu perusahaan, suatu industri atau suatu perekonomian secara keseluruhan. Dengan menyederhanakan persoalan, maka dapat dimisalkan bahwa pada tingkat teknologi tertentu, fungsi produksi lada putih adalah sebagai berikut:

$$
\mathbf{Q L P}=\mathbf{q}(\mathbf{J P}, \mathbf{J T K}, \mathrm{JZ})
$$

dimana:

$$
\begin{array}{ll}
\text { QLP } & =\text { Jumlah produksi lada putih } \\
\text { JL } & =\text { Jumlah pupuk } \\
\text { JTK } & =\text { Jumlah tenaga kerja } \\
\text { JZ } & =\text { Masukan produksi lainnya }
\end{array}
$$

Jika diketahui bahwa harga masukan pupuk, tenaga kerja, dan masukan produksi lainnya masing-masing adalah HP, W, dan HZ, maka persamaan biaya produksi total dapat dirumuskan sebagai berikut:

$$
\begin{aligned}
\mathbf{C}= & \mathbf{H P} * \mathbf{J P}+\mathbf{W} * \mathbf{J T K}+\mathbf{H Z} * \mathbf{J Z}+\mathbf{C}^{\mathbf{o}} \\
& \mathrm{C}=\text { Biaya total dan } \mathrm{C}^{\mathrm{o}} \text { adalah biaya tetap }
\end{aligned}
$$

Keuntungan didefinisikan sebagai selisih antara penerimaan dan biaya-biaya. Dengan demikian fungsi keuntungan petani lada putih dapat dirumuskan sebagai berikut:

$$
\begin{aligned}
\Pi= & \mathbf{H Q L P} * \mathbf{Q L P}-\mathbf{C} \\
\Pi= & \underset{*}{\mathbf{H Q L P}} * \mathbf{q}(\mathbf{J P}, \mathbf{J T K}, \mathbf{J Z})-\left(\mathbf{H P} * \mathbf{J P}+\underset{\mathbf{W}}{\mathbf{W}}+\mathbf{H Z} * \mathbf{J Z}+\mathbf{C}^{\mathbf{0}}\right)
\end{aligned}
$$

dimana:

$$
\Pi=\begin{aligned}
\text { Keuntungan dan HQLP adalah harga } \\
\text { lada putih }
\end{aligned}
$$

Dengan asumsi berperilaku rasional, petani akan berupaya memproduksi lada putih pada tingkat yang memberikan keuntungan maksimum. Fungsi keuntungan (4) akan maksimum apabila turunan pertama dari fungsi tersebut sama dengan nol. Turunan parsial dari fungsi (4) adalah:

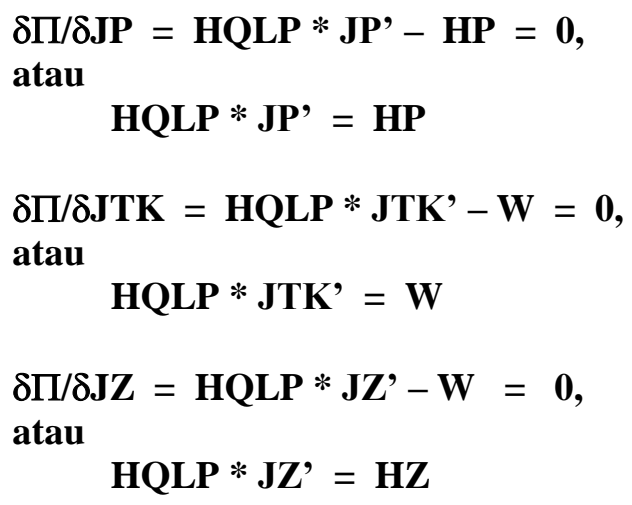

dimana:

JP', JTK' dan JZ' masing-masing adalah produk marginal dari masukan pupuk (JP), tenaga kerja (JTK), dan masukan produk lada putih lainnya (JZ). Dengan demikian berdasarkan syarat orde satu, keuntungan petani akan maksimum apabila pada suatu tingkat produksi tertentu diperoleh nilai produk marginal masing-masing masukan produksi sama dengan harga yang harus dibayar untuk memperoleh masukan-masukan tersebut. Lebih lanjut lagi fungsi (5), (6), dan (7) dapat pula diekspresikan sebagai berikut:

$$
\begin{aligned}
& \mathrm{JP}^{\prime}=\text { HQLP } / \mathrm{HP} \\
& \mathrm{JTK}^{=}=\mathrm{HQLP} / \mathrm{W} \\
& \mathrm{JZ}=\mathrm{HQLP} / \mathrm{HZ}
\end{aligned}
$$

Dengan kata lain keuntungan maksimum petani dari produksi lada putih dapat dicapai pada kondisi dimana produk marginal dari masingmasing masukan pupuk, tenaga kerja, dan masukan produksi lainnya sama dengan rasio harga lada putih dan harga masing-masing masukan tersebut. Kemudian dalam kasus fungsi (8), (9), dan (10) tersebut dapat dinyatakan bahwa masukan produksi JK, JTK, dan JZ merupakan peubah endogen, sedangkan harga lada putih (HQLP) dan harga-harga masukan (HP, W, dan HZ) merupakan peubah eksogen. Oleh karena itu, fungsi permintaan masukan produksi dapat dirumuskan sebagai berikut: 
$\mathrm{JP}^{\mathrm{D}}=\mathbf{p}(\mathrm{HP}, \mathrm{HQLP}, \mathbf{W}, \mathbf{H Z}$

$J_{T K P}{ }^{D}=\operatorname{tk}(W, H Q L P, H P, H Z$

$\mathrm{JZ}^{\mathrm{D}}=\mathbf{z}(\mathrm{HZ}, \mathrm{HQLP}, \mathrm{HP}, \mathrm{W})$

dimana:

$\mathrm{JP}^{\mathrm{D}}, \mathrm{JTK}^{\mathrm{D}}$, dan $\mathrm{JZ}^{\mathrm{D}}$ masing-masing adalah permintaan terhadap masukan pupuk, tenaga kerja, dan masukan lainnya. Dengan mensubstitusikan fungsi permintaan masukan (11), (12), dan (13) ke fungsi produksi (1), maka fungsi produksi (penawaran) lada putih pada suatu tahun tertentu (QLP) dapat dirumuskan sebagai berikut:

$\mathrm{QLP}_{\mathrm{t}}=\mathbf{q}\left(\mathrm{HQLPI}_{\mathrm{t}}, \mathrm{HP}_{\mathrm{t}}, \mathrm{W}_{\mathrm{t}}, \mathrm{HZ}_{\mathrm{t}}\right)$

\section{b. Penawaran Ekspor dan Permintaan Impor Lada Putih}

Analisis penawaran ekspor dan permintaan impor di pasar dunia, dapat dilakukan secara sederhana, yaitu dengan menggunakan konsep dasar fungsi penawaran dan permintaan domestik untuk kasus dua negara dengan suatu komoditi perdagangan tertentu (Caves, et al, 1993), misalnya lada putih.

Secara umum, ekspor komoditas dari suatu negara merupakan kelebihan penawaran domestik atau produksi komoditas itu yang tidak dibeli konsumen tersebut atau tidak disimpan dalam bentuk stok (Labys, 1973), karena adanya rangsangan harga dunia yang lebih tinggi dari harga domestik. Dengan demikian ekspor lada putih Indonesia dapat didefinisikan sebagai berikut:

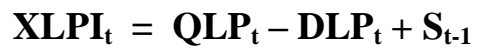

dimana:

$\mathrm{XLPI}_{\mathrm{t}}=$ Volume ekspor lada putih Indonesia pada tahun $\mathrm{t}$

$\mathrm{QLP}_{\mathrm{t}}=$ Total produksi lada putih Indonesia pada tahun $t$

$\mathrm{DLP}_{\mathrm{t}}=$ Penawaran lada putih Indonesia di pasar domestik pada tahun $t$

$\mathrm{S}_{\mathrm{t}-1} \quad=$ Stok lada putih Indonesia setahun sebelum $\mathrm{t}$
Apabila tidak ada stok, maka ekspor lada putih secara sederhana sama dengan selisih antara jumlah produksi lada putih dengan jumlah yang ditawarkan (diminta) di pasar domestik. Dengan asumsi bahwa impor lada putih negara pengekspor relatif sangat kecil dibandingkan dengan jumlah produksinya, sehingga hal ini dapat diabaikan. Konsumsi domestik negara produsen pada umumnya relatif stabil sehingga dapat diabaikan. Selanjutnya, ekspor lada putih yang dikemukakan pada persamaan (15) hanya berupa identitas yang tidak diketahui prilakunya. Mengingat adanya peranan pasar lada putih dunia, produksi lada putih dan faktor-faktor lain seperti nilai tukar uang, tingkat suku bunga dan kebijakan ekspor, maka secara teoritis penawaran ekspor lada putih Indonesia dapat dibuat persamaan perilakunya dengan mempertimbangkan kondisi penyesuaian parsial, yaitu:

\section{XLPI $_{t}=\mathbf{f} \quad\left(\right.$ HXLPI $_{t}, \quad$ HXLHI $_{t}, \quad$ QLPIK $_{t}$, NTRIA $_{t}$, IRI $_{t}$, XLPI $_{t-1}$ )

dimana:

$\begin{aligned} \text { HXLPI }_{\mathrm{t}}= & \text { Harga ekspor lada putih } \\ & \text { Indonesia pada tahun } \mathrm{t} \\ \text { HXLHI }_{\mathrm{t}}= & \text { Harga ekspor lada hitam } \\ & \text { Indonesia pada tahun } \mathrm{t} \\ \text { QLPIK }_{\mathrm{t}}= & \begin{array}{l}\text { Produksi lada putih Indonesia } \\ \text { pada tahun } \mathrm{t}\end{array} \\ \text { NTRIA }_{\mathrm{t}}= & \begin{array}{l}\text { Nilai tukar rupiah terhadap } \\ \text { dollar USA pada tahun } \mathrm{t}\end{array} \\ \text { IRI }_{\mathrm{t}}= & \text { Tingkat suku bunga Indonesia } \\ \text { pada tahun } \mathrm{t} & \\ \text { XLPI }_{\mathrm{t}-1}= & \begin{array}{l}\text { Volume ekspor lada putih } \\ \text { Indonesia setahun sebelum } \mathrm{t}\end{array}\end{aligned}$

Apabila ingin diketahui peranan ekspor lada putih Indonesia terhadap ekspor lada putih dunia, yang pada gilirannya akan mempengaruhi prilaku harga lada putih dunia, maka dapat dirumuskan dalam persamaan berikut:

$\mathrm{XLPW}_{\mathrm{t}}=\mathrm{XLPI}_{\mathrm{t}}+\mathrm{XLPZ}_{\mathrm{t}}$

dimana:

$\begin{aligned} \mathrm{XLPW}_{\mathrm{t}}= & \text { Volume ekspor lada putih dunia } \\ & \text { pada tahun } \mathrm{t} \\ \mathrm{XLPI}_{\mathrm{t}}= & \text { Volume ekspor lada putih } \\ & \text { Indonesia pada tahun } \mathrm{t}\end{aligned}$ 
$\mathrm{XLPZ}_{\mathrm{t}}=\underset{\text { Volume ekspor lada putih }}{\text { negara lain pada tahun } \mathrm{t}}$

Selanjutnya, permintaan impor suatu negara merupakan kelebihan konsumsi yang tidak dapat diproduksi (Laby, 1973). Dengan kata lain impor dapat terjadi jika jumlah konsumsi akan suatu barang melebihi produksi dan stok barang tersebut pada tahun lalu. Dengan demikian permintaan impor suatu negara dapat dirumuskan sebagai berikut:

$\operatorname{MLP}_{t}=\mathbf{C L P}_{t}-\mathbf{Q L P}_{t}+\mathrm{S}_{\mathrm{t}-1}$

dimana:

$$
\begin{aligned}
\mathrm{MLP}_{\mathrm{t}}= & \text { Volume impor lada putih suatu } \\
& \text { negara pada tahun } \mathrm{t} \\
\mathrm{DLP}_{\mathrm{t}}= & \begin{array}{l}
\text { Konsumsi lada putih suatu } \\
\text { negara pada tahun } \mathrm{t}
\end{array} \\
\mathrm{QLP}_{\mathrm{t}}= & \begin{array}{l}
\text { Produksi lada putih suatu negara } \\
\text { pada tahun } \mathrm{t}
\end{array} \\
\mathrm{S}_{\mathrm{t}-1}= & \begin{array}{l}
\text { Jumlah stok lada putih suatu } \\
\text { negara setahun sebelum } \mathrm{t}
\end{array}
\end{aligned}
$$

Dalam persamaan (18) diasumsikan bahwa reekspor lada putih dari negara-negara konsumen tertentu adalah relatif kecil dibandingkan dengan impor, sehingga dapat diabaikan. Pada umumnya negara-negara importir lada putih tidak memproduksi sendiri komoditi tersebut karena keadaan iklim yang tidak mendukung. Dengan demikian fungsi permintaan impor lada putih suatu negara dapat dirumuskan sebagai berikut:

$$
\begin{aligned}
& \text { MLP }_{t}=\mathbf{f}\left(\text { HMLP }_{t}, \text { HMLH }_{t}, \text { NTR }_{t}, Z_{t}\right. \text {, } \\
& \text { MLP } \left._{t-1}\right)
\end{aligned}
$$

dimana:

MLP $_{\mathrm{t}}=$ Volume impor lada putih suatu negara pada tahun $\mathrm{t}$

HMLP $_{\mathrm{t}}=$ Harga impor lada putih suatu negara pada tahun $\mathrm{t}$

$\mathrm{HMLH}_{\mathrm{t}}=$ Harga impor komoditi substitusi suatu negara pada tahun $\mathrm{t}$

NTR $_{\mathrm{t}}=$ Nilai tukar mata uang suatu negara terhadap dollar USA pada tahun $\mathrm{t}$

$\mathrm{Z}_{\mathrm{t}}=$ Faktor-faktor lainnya pada tahun $\mathrm{t}$

$\mathrm{MLP}_{\mathrm{t}-1}=$ Volume impor lada putih suatu negara setahun sebelum $t$

\section{c. Keterkaitan Harga lada Putih}

Mekanisme perubahan harga lada putih di pasar dunia dapat terjadi, baik karena kekuatankekuatan yang mempengaruhi perubahan penawaran ekspor, permintaan impor, maupun karena pengaruh keduanya secara bersama-sama. Selain itu, dapat juga dipengaruhi oleh tingkat harga dunia yang berlaku sebelumnya. Secara fungsional hubungannya dapat dituliskan sebagai berikut:

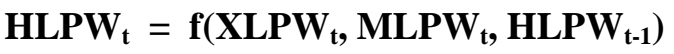

dimana:

$\mathrm{HLPW}_{\mathrm{t}}=$ Harga lada putih di pasar dunia pada tahun $\mathrm{t}$

$\mathrm{XLPW}_{\mathrm{t}}=$ Volume ekspor lada putih dunia pada tahun $\mathrm{t}$

$\mathrm{MLPW}_{\mathrm{t}}=$ Volume impor lada putih dunia pada tahun $\mathrm{t}$

$\mathrm{HLPW}_{\mathrm{t}-1}=$ Harga lada putih di pasar dunia setahun sebelum $\mathrm{t}$

Kekuatan mekanisme harga di pasar dunia dapat mempengaruhi mekanisme pasar domestik dan sebaliknya (Librero, 1971). Dengan demikian jika harga lada putih di pasar dunia mengalami kenaikan, maka akan berdampak terhadap kenaikan harga lada putih, baik di tingkat eksportir, importir, dan petani domestik. Dengan kata lain suatu pasar dapat terintegrasi dengan pasar lainnya, bila informasi mudah diperoleh pada bursa masing-masing negara. Untuk mengetahui seberapa besar pengaruhnya, maka prilaku harga ekspor dan harga impor suatu negara dapat dirumuskan sebagai berikut:

HXLP $_{t}=\mathbf{f}\left(\mathrm{HLPW}_{\mathrm{t}}, \mathrm{XLP}_{\mathrm{t}}, \mathrm{HXLP}_{\mathrm{t}-1}\right)$

$\operatorname{HMLP}_{t}=\mathbf{f}\left(\mathrm{HLPW}_{t}, \mathrm{MLP}_{\mathrm{t}}, \mathrm{HMLP}_{\mathrm{t}-1}\right)$

dimana:

Dipertimbangkan juga pengaruh volume ekspor dan impor lada putih, serta penyesuaian parsial harga ekspor dan impor tersebut. Selanjutnya, harga di tingkat petani juga dapat dirumuskan prilakunya dengan memasukkan peubah-peubah penentunya, seperti harga ekspor lada putih, produksi lada putih, dan penyesuaian parsial harga 
petani tersebut. Bentuk fungsionalnya dapat dituliskan:

HLPI $_{t}=\mathbf{f}\left(\mathrm{HXLPI}_{t}, \mathbf{Q L P}_{t}\right.$, HLPI $\left._{t-1}\right)$

\section{Model Ekonomi}

Dasar untuk membangun model ekonomi dari komoditi lada di Indonesia dan keterkaitan ekonomi dari peubah-peubah dalam sistem ekonomi yang dirumuskan ke dalam model struktural, kemudian model akan digunakan untuk analisis empiris maupun evaluasi kebijakan.

\section{Model Ekonometrika}

Pada bagian ini akan dijelaskan mengenai perumusan persamaan yang spesifik dari peubahpeubah penjelas (explanatory variable) yang digunakan dalam model ekonomi komoditi lada ini. Ada beberapa blok persamaan dalam model yaitu blok penawaran ekspor Indonesia, penawaran ekspor dunia, penawaran domestik dan harga. Adapun model ekonometrika yang menggambarkan hubungan masing-masing peubah penjelas terhadap peubah endogen secara terperinci dirumuskan dalam 13 persamaan. Hal ini secara lengkap dapat dilihat pada Tabel 1.
Variabel Endogenous:

QLPIA $_{\mathrm{t}}=$ Produksi lada putih asalan Indonesia (ton)

$\mathrm{QLPIK}_{\mathrm{t}}=$ Produksi lada putih kering Indonesia (ton)

$\mathrm{QS}_{\mathrm{t}}=$ Volume penawaran lada putih domestik (ton))

$\mathrm{XLPA}_{\mathrm{t}}=$ Volume ekspor lada putih Indonesia ke Amerika Serikat (ton)

$\mathrm{XLPJ}_{\mathrm{t}}=$ Volume ekspor lada putih Indonesia ke Jerman (ton)

$\mathrm{XLPN}_{\mathrm{t}}=$ Volume ekspor lada putih Indonesia ke Nederland (ton)

$\mathrm{XLPP}_{\mathrm{t}}=$ Volume ekspor lada putih Indonesia ke Jepang (ton)

$\mathrm{XLPS}_{\mathrm{t}}=$ Volume ekspor lada putih Indonesia ke Singapura (ton)

$\mathrm{XLPI}_{\mathrm{t}}=$ Volume eskpor Indonesia (ton)

$\mathrm{XLPW}_{\mathrm{t}}=$ Total ekspor lada putih dunia (ton)

$\mathrm{HLPW}_{\mathrm{t}}=$ Harga rill lada putih di pasar dunia (US\$/kg)

HXLPI $_{t}=$ Harga ekspor rill lada putih Indonesia (US\$/kg)

$\mathrm{HLPI}_{\mathrm{t}} \quad=$ Harga rill lada putih di level petani $(\mathrm{Rp} / \mathrm{kg})$

Tabel 1. Model Ekonometrika Lada Indonesia

\begin{tabular}{|c|c|c|c|}
\hline No & Persamaan & Model Ekonometrika & $\begin{array}{c}\text { Tanda } \\
\text { Parameter }\end{array}$ \\
\hline 1 & $\begin{array}{l}\text { Produksi lada putih } \\
\text { asalan Indonesia } \\
\text { (ton) }\end{array}$ & $\begin{aligned} \text { QLPIA }_{\mathrm{t}}= & \mathrm{a}_{\mathrm{o}}+\mathrm{a}_{1} \mathrm{HLPI}_{\mathrm{t}}+\mathrm{a}_{2}\left(\mathrm{HLHI}_{\mathrm{t}}-\mathrm{HLHI}_{\mathrm{t}-1}\right)+ \\
& \mathrm{a}_{3} \mathrm{HF}_{\mathrm{t}}+\mathrm{a}_{4} \mathrm{IRI}_{\mathrm{t}}+\mathrm{a}_{5} \mathrm{~W}_{\mathrm{t}}+\mathrm{a}_{6} \mathrm{CHSS}_{\mathrm{t}} \\
& +\mathrm{a}_{7} \text { LLPIA }_{\mathrm{t}}+\mathrm{a}_{8}\left(\text { YLPIA }_{\mathrm{t}} \text { YLPIA }_{\mathrm{t}-1}\right)+ \\
& \mathrm{a}_{9} \text { QLPIA }_{\mathrm{t}-1}+\mathrm{U}_{1}\end{aligned}$ & $\begin{array}{l}a_{1}, a_{7}, a_{8}>0 \\
a_{2}, a_{3}, a_{4}, a_{5}, a_{6}<0 \\
0<a_{9}<1\end{array}$ \\
\hline 2 & $\begin{array}{l}\text { Produksi lada putih } \\
\text { kering Indonesia } \\
\text { (ton) }\end{array}$ & $\mathrm{QLPIK}_{\mathrm{t}}=0.952 * \mathrm{QLPIA}_{\mathrm{t}}$ & \\
\hline 3 & $\begin{array}{l}\text { Volume penawaran } \\
\text { lada putih domestik } \\
\text { (ton) }\end{array}$ & $\mathrm{QS}_{\mathrm{t}}=\mathrm{QLPIA}_{\mathrm{t}}-\mathrm{XLPI}_{\mathrm{t}}$ & \\
\hline 4 & $\begin{array}{l}\text { Volume ekspor lada } \\
\text { putih Indonesia ke } \\
\text { Amerika Serikat } \\
\text { (ton) }\end{array}$ & $\begin{aligned} \mathrm{XLPA}_{\mathrm{t}}= & \mathrm{b}_{\mathrm{o}}+\mathrm{b}_{1}\left(\mathrm{HXLPI}_{\mathrm{t}}-\mathrm{HXLPI}_{\mathrm{t}-1}\right)+\mathrm{b}_{2} \\
& \left(\mathrm{HXLHI}_{\mathrm{t}}-\mathrm{HXLHI}_{\mathrm{t}-1}\right)+\mathrm{b}_{3}\left(\mathrm{QLPIK}_{\mathrm{t}}-\right. \\
& \left.\mathrm{QLPIK}_{\mathrm{t}-1}\right)+\mathrm{b}_{4} \text { NTRIA }_{\mathrm{t}}+\mathrm{b}_{5} \text { IRI }_{\mathrm{t}}+ \\
& \mathrm{b}_{6} \mathrm{DM}_{1 \mathrm{t}}+\mathrm{b}_{7} \text { RXLPS }_{\mathrm{t}}+\mathrm{b}_{8} \mathrm{XLPA}_{\mathrm{t}-1}+\mathrm{U}_{2}\end{aligned}$ & $\begin{array}{l}b_{1}, b_{3}, b_{4}, b_{6}>0 \\
b_{2}, b_{5}, b_{7}<0 \\
0<b_{8}<1\end{array}$ \\
\hline
\end{tabular}




\begin{tabular}{|c|c|c|c|c|}
\hline 5 & $\begin{array}{l}\text { Volume ekspor lada } \\
\text { putih Indonesia ke } \\
\text { Jerman (ton) }\end{array}$ & $\mathrm{XLPJ}_{\mathrm{t}}$ & $\begin{array}{l}=c_{\mathrm{o}}+\mathrm{c}_{1} \mathrm{HXLPI}_{\mathrm{t}}+\mathrm{c}_{2}\left(\mathrm{HXLHI}_{\mathrm{t}}-\right. \\
\left.\mathrm{HXLHI}_{\mathrm{t}-1}\right)+\mathrm{c}_{3} \mathrm{QLPIK}_{\mathrm{t}}+\mathrm{c}_{4}\left(\mathrm{NTRIA}_{\mathrm{t}}-\right. \\
\left.\text { NTRIA }_{\mathrm{t}-1}\right)+\mathrm{c}_{5} \mathrm{IRI}_{\mathrm{t}}+\mathrm{c}_{6} \mathrm{DM}_{1 \mathrm{t}}+ \\
\mathrm{c}_{7} \text { RXLPS }_{\mathrm{t}}+\mathrm{c}_{8} \text { XLPJ }_{\mathrm{t}-1}+\mathrm{U}_{3}\end{array}$ & $\begin{array}{l}\mathrm{c}_{1}, \mathrm{c}_{3}, \mathrm{c}_{4}, \mathrm{c}_{6}>0 \\
\mathrm{c}_{2}, \mathrm{c}_{5}, \mathrm{c}_{7}<0 \\
0<\mathrm{c}_{8}<1\end{array}$ \\
\hline 6 & $\begin{array}{l}\text { Volume ekspor lada } \\
\text { putih Indonesia ke } \\
\text { Nederland (ton) }\end{array}$ & $\mathrm{XLPN}_{\mathrm{t}}$ & $\begin{array}{l}=\mathrm{d}_{\mathrm{o}}+\mathrm{d}_{1}\left(\mathrm{HXLPI}_{\mathrm{t}}-\mathrm{HXLPI}_{\mathrm{t}-1}\right)+\mathrm{d}_{2} \\
\left(\mathrm{HXLHI}_{\mathrm{t}}-\mathrm{HXLHI}_{\mathrm{t}-1}\right)+\mathrm{d}_{3} \mathrm{QLPIK} \mathrm{H}_{\mathrm{t}}+ \\
\mathrm{d}_{4} \text { NTRIA }_{\mathrm{t}}+\mathrm{d}_{5} \mathrm{IRI}_{\mathrm{t}}+\mathrm{d}_{6} \mathrm{DM}_{1 \mathrm{t}}+ \\
\mathrm{d}_{7} \text { RXLPS }_{\mathrm{t}}+\mathrm{d}_{8} \mathrm{XLPN}_{\mathrm{t}-1}+\mathrm{U}_{4}\end{array}$ & $\begin{array}{l}\mathrm{d}_{1}, \mathrm{~d}_{3}, \mathrm{~d}_{4}, \mathrm{~d}_{6}>0 \\
\mathrm{~d}_{2}, \mathrm{~d}_{5}, \mathrm{~d}_{7}<0 \\
0<\mathrm{d}_{8}<1\end{array}$ \\
\hline 7 & $\begin{array}{l}\text { Volume ekspor lada } \\
\text { putih Indonesia ke } \\
\text { Jepang (ton) }\end{array}$ & $\mathrm{XLPP}_{\mathrm{t}}$ & $\begin{array}{l}=\mathrm{e}_{\mathrm{o}}+\mathrm{e}_{1}\left(\mathrm{HXLPI}_{\mathrm{t}}-\mathrm{HXLPI}_{\mathrm{t}-1}\right)+\mathrm{e}_{2} \\
\left(\mathrm{HXLHI}_{\mathrm{t}}-\mathrm{HXLHI}_{\mathrm{t}-1}\right)+\mathrm{e}_{3}\left(\mathrm{QLPII}_{\mathrm{t}^{-}}\right. \\
\left.\mathrm{QLPIK}_{\mathrm{t}-1}\right)+\mathrm{e}_{4} \mathrm{NTRIA}_{\mathrm{t}}+\mathrm{e}_{5} \mathrm{IRI}_{\mathrm{t}}+ \\
\mathrm{e}_{6} \mathrm{DM}_{1 \mathrm{t}}+\mathrm{e}_{7}\left(\mathrm{RXLPS}_{\mathrm{t}^{-}}\right. \\
\left.\operatorname{RXLPS}_{\mathrm{t}-1}\right)+\mathrm{e}_{8} \mathrm{XLPP}_{\mathrm{t}-1}+\mathrm{U}_{5}\end{array}$ & $\begin{array}{l}\mathrm{e}_{1}, \mathrm{e}_{3}, \mathrm{e}_{4}, \mathrm{e}_{6}>0 \\
\mathrm{e}_{2}, \mathrm{e}_{5}, \mathrm{e}_{7}<0 \\
0<\mathrm{e}_{8}<1\end{array}$ \\
\hline 8 & $\begin{array}{l}\text { Volume ekspor lada } \\
\text { putih Indonesia ke } \\
\text { Singapura (ton) }\end{array}$ & $\mathrm{XLPS}_{\mathrm{t}}$ & $\begin{array}{l}=\mathrm{f}_{\mathrm{o}}+\mathrm{f}_{1}\left(\mathrm{HXLPI}_{\mathrm{t}}-\mathrm{HXLPI}_{\mathrm{t}-1}\right)+ \\
\mathrm{f}_{2} \mathrm{HXLHI}_{\mathrm{t}}+\mathrm{f}_{3}\left(\mathrm{QLPIK}_{\mathrm{t}} \mathrm{QLPIK} \mathrm{QLI}_{\mathrm{t}-1}\right)_{\mathrm{t}}+ \\
\mathrm{f}_{4} \mathrm{NTRIA}_{\mathrm{t}}+\mathrm{f}_{5} \mathrm{IRI}_{\mathrm{t}}+\mathrm{f}_{6} \mathrm{DM}_{1 \mathrm{t}}+ \\
\mathrm{f}_{7} \text { RXLPS }_{\mathrm{t}}+\mathrm{f}_{8} \text { XLPS }_{\mathrm{t}-1}+\mathrm{U}_{6}\end{array}$ & $\begin{array}{l}\mathrm{f}_{1}, \mathrm{f}_{3}, \mathrm{f}_{4}, \mathrm{f}_{6}>0 \\
\mathrm{f}_{2}, \mathrm{f}_{5}, \mathrm{f}_{7}<0 \\
0<\mathrm{f}_{8}<1\end{array}$ \\
\hline 9 & $\begin{array}{l}\text { Total ekspor lada } \\
\text { putih Indonesia (ton) }\end{array}$ & $\mathrm{XLPI}_{\mathrm{t}}$ & $\begin{array}{l}=\mathrm{XLPA}_{t}+\mathrm{XLPJ}_{\mathrm{t}}+\mathrm{XLPN}_{\mathrm{t}}+ \\
\mathrm{XLPP}_{\mathrm{t}}+\mathrm{XLPS}_{\mathrm{t}}+\mathrm{XLPR}_{\mathrm{t}}\end{array}$ & \\
\hline 10 & $\begin{array}{l}\text { Total ekspor lada } \\
\text { putih dunia (ton) }\end{array}$ & $\mathrm{XLPW}_{\mathrm{t}}$ & $=\mathrm{XLPI}_{\mathrm{t}}+\mathrm{XLPM}_{\mathrm{t}}+\mathrm{XLPB}_{\mathrm{t}}+\mathrm{XLPH}_{\mathrm{t}}$ & \\
\hline 11 & $\begin{array}{l}\text { Harga rill lada putih } \\
\text { di pasar dunia } \\
\text { (US } \$ / \mathrm{kg} \text { ) }\end{array}$ & $\mathrm{HLPW}_{\mathrm{t}}$ & $\begin{aligned}= & \mathrm{g}_{0}+\mathrm{g}_{1} \mathrm{XLPW}_{\mathrm{t}}+\mathrm{g}_{2} \mathrm{MLPW}_{\mathrm{t}}+\mathrm{g}_{3} \mathrm{HLPW}_{\mathrm{t}-} \\
& { }_{1}+\mathrm{U}_{7}\end{aligned}$ & $\begin{array}{l}\mathrm{g}_{2}>0 \\
\mathrm{~g}_{1}<0 \\
0<\mathrm{g}_{3}<1\end{array}$ \\
\hline 12 & $\begin{array}{l}\text { Harga ekspor rill } \\
\text { lada putih Indonesia } \\
\text { (US\$/kg) }\end{array}$ & HXLPI $_{t}$ & $\begin{aligned}= & \mathrm{h}_{0}+\mathrm{h}_{1} \mathrm{HLPW}_{\mathrm{t}}+\mathrm{h}_{2} \mathrm{XLPI}_{\mathrm{t}}+\mathrm{h}_{3} \mathrm{HXLPI}_{\mathrm{t}-} \\
& { }_{1}+\mathrm{U}_{8}\end{aligned}$ & $\begin{array}{l}\mathrm{h}_{1}>0 \\
\mathrm{~h}_{2}<0 \\
0<\mathrm{h}_{3}<1\end{array}$ \\
\hline 13 & $\begin{array}{l}\text { Harga rill lada putih } \\
\text { tk. petani }(\mathrm{Rp} / \mathrm{kg})\end{array}$ & $\mathrm{HLPI}_{\mathrm{t}}$ & $\begin{aligned}= & \mathrm{i}_{0}+\mathrm{i}_{1}\left(\mathrm{HXLPI}_{\mathrm{t}} / \mathrm{LHXLPI}_{\mathrm{t}}\right)+\mathrm{i}_{2} \\
& \left(\mathrm{QS}_{\mathrm{t}} / \mathrm{LQS}_{\mathrm{t}-1}\right)+\mathrm{i} 3 \mathrm{LHLPI}_{\mathrm{t}-1}+\mathrm{U}_{9}\end{aligned}$ & $\begin{array}{l}\mathrm{i}_{1}>0 \\
\mathrm{i}_{2}<0 \\
0<\mathrm{i}_{3}<1\end{array}$ \\
\hline
\end{tabular}

\section{Variabel Exogenous:}

$\mathrm{HLHI}_{\mathrm{t}}=$ Harga rill lada hitam di tingkat petani $(\mathrm{Rp} / \mathrm{kg})$

$\mathrm{HF}_{\mathrm{t}}=$ Harga rill pupuk di tingkat petani $(\mathrm{rp} / \mathrm{kg})$

$\mathrm{W}_{\mathrm{t}} \quad=$ Tingkat upah tenaga kerja sub sektor perkebunan (rupiah)IRI $\mathrm{I}_{\mathrm{t}}=$

Tingkat suku bunga umum Indonesia (\%/tahun)

CHSS $_{\mathrm{t}}=$ Jumlah curah hujan rata-rata Propinsi Sumatera Selatan ( $\mathrm{mm} / \mathrm{tahun})$

LLPIA $_{t}=$ Luas areal panen lada putih Indonesia (hektar)
YLPIA $_{\mathrm{t}}=$ Produktivitas lada putih Indonesia (ton/hektar)

QLPIA $_{\mathrm{t}-1}=$ Peubah bedakala dari QLPIA $_{\mathrm{t}}$ (ton)

HXLPI $_{t}=$ Harga rill ekspor lada putih Indonesia (US\$ $/ \mathrm{kg}$ )

$\mathrm{HXLHI}_{\mathrm{t}}=$ Harga rill ekspor lada hitam Indonesia (US\$ $/ \mathrm{kg}$ )

NTRIA $_{\mathrm{t}}=$ Nilai tukar mata uang Indonesia terhadap US \$ (rp/US\$)

$\mathrm{XLPR}_{\mathrm{t}}=$ Volume ekspor lada putih Indonesia ke negara sisa dunia (ton)

RXLPS $_{\mathrm{t}}=$ Volume reekspor lada putih Singapura (ton)

$\mathrm{MLPW}_{\mathrm{t}}=$ Impor lada putih dunia (ton) 


\section{Variabel Bedakala (lag):}

$\mathrm{XLPA}_{\mathrm{t}-1}=$ Peubah bedakala dari $\mathrm{XLPA}_{\mathrm{t}}$ (ton)

$\mathrm{XLPJ}_{\mathrm{t}-1}=$ Peubah bedakala dari $\mathrm{XLPJ}_{\mathrm{t}}$ (ton)

$\mathrm{XLPN}_{\mathrm{t}-1}=$ Peubah bedakala dari $\mathrm{XLPN}_{\mathrm{t}}$ (ton)

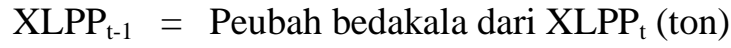

$\mathrm{XLPS}_{\mathrm{t}-1}=$ Peubah bedakala dari $\mathrm{XLPS}_{\mathrm{t}}$ (ton)

HLPW $_{\mathrm{t}-1}=$ Peubah bedakala dari $\mathrm{HLPW}_{\mathrm{t}}$ (US\$/kg)

HXLPI $_{\mathrm{t}-1}=$ Peubah bedakala dari HXLPI (US\$/kg)

HXLPM $_{\mathrm{t}-1}=$ Peubah bedakala dari HXLPM $_{\mathrm{t}}$ (US\$/kg)

HXLPB $_{\mathrm{t}-1}=$ Peubah bedakala dari HXLPB $_{\mathrm{t}}$ (US\$/kg)

HLPI $_{\mathrm{t}-1} \quad=$ Peubah bedakala dari HLPI $(\mathrm{Rp} / \mathrm{kg})$

$\mathrm{QS}_{\mathrm{t}} \quad=$ Penawaran lada putih Indoensia (ton)

Variabel Dummy:

$\mathrm{DM}_{\mathrm{t}}=$ Dummy standar mutu Indonesia, dimana $1=$ untuk tahun 1975-2006 dan $0=$ sebelum tahun 1975 .

\section{Identifikasi Model}

Model persamaan struktural bersifat berganda dengan demikian perlu dilakukan lebih dahulu identifikasi model sebelum memilih metode untuk menduga parameter setiap persamaan dalam model tersebut. Berkaitan dengan itu pendugaan parameter suatu model persamaan struktural harus didahului dengan identifikasi. Rumusan identifikasi model persamaan struktural berdasarkan adalah sebagai berikut:

$$
(\mathbf{K}-\mathbf{M}) \geq(\mathbf{G}-\mathbf{1})
$$

dimana:

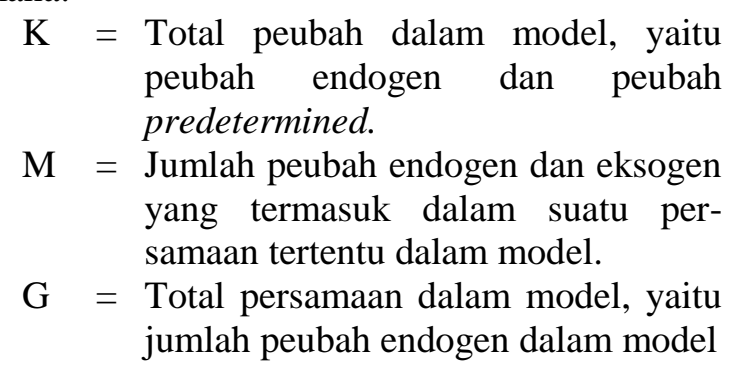

Adapun kriteria:

Jika $(\mathrm{K}-\mathrm{M})>(\mathrm{G}-1)$, maka overidentified

Jika $(\mathrm{K}-\mathrm{M})=(\mathrm{G}-1)$, maka exactlyidentified
Jika $(\mathrm{K}-\mathrm{M})<(\mathrm{G}-1)$, maka unidentified.

Model persamaan simultan dalam penelitian ini mempunyai 13 peubah endogen $(\mathrm{G}), 27$ peubah predetermin (predetermined variables) yang terdiri dari 17 peubah eksogen dan 10 peubah bedakala endogen (lagged endogenous variables). Dengan demikian total seluruh peubah dalam model (K) berjumlah 40 peubah. Berdasarkan ketentuan kriteria rumus identifikasi model dengan order condition di atas, maka setiap persamaan struktural simultan yang disusun dalam penelitian ini teridentifikasi berlebih (overidentified).

\section{Simulasi Kebijakan}

Setelah model divalidasi dan memenuhi kriteria secara statistika maka model tersebut sangat baik untuk digunakan sebagai model dasar simulasi. Dalam studi ini digunakan data time series tahun 1975-2004 $(\mathrm{n}=30)$. Simulasi yang buat dilakukan pada 5 tahun terakhir (Tahun 1999-2004), pada periode tersebut disebut ex-post simulation atau historical simulation. Nilai historical simulation dimulai dari tahun $\mathrm{T}_{1}$ dan berakhir pada tahun $\mathrm{T}_{2}$, yang digunakan adalah untuk peubah eksogen, sedangkan nilai historical dalam $\mathrm{T}_{1}$ merupakan keadaan awal dari peubah endogen.

Analisis simulasi adalah untuk mengetahui dampak perubahan kebijakan dan faktor-faktor ekonomi eskternal terhadap peubah endogen dalam model. Adapun skenario untuk simulasi historis adalah (a) Peningkatan harga pupuk sebesar $15 \%$, (b) Penurunan tingkat suku bunga sebesar 5\% dan (c) Kombinasi dari simulasi 1 dan 2.

\section{Kesejahteraan Produsen di Level Petani Lada}

Dalam studi ini alternatif kebijakan untuk menganalisis kesejahteraan produsen lada di level petani yang diukur melalui surplus produsen pada periode yang selalu dilakukan penciptaan, sehingga dampak kesejahteraan masyarakat merupakan indikator kebijakan terhadap penentuan arah kebijakan akan dilakukan. Dengan demikian, studi ini melihat kesejahteraan petani yang memproduksi lada putih asalan dan petani yang memproduksi lada putih kering. Adapun rumus yang akan digunakan adalah: 
Untuk menghitung surplus produsen (petani lada) yang memproduksi jenis lada putih asalan dengan rumus:

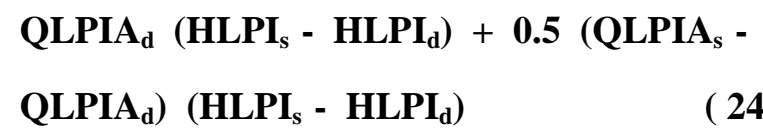

dimana:

$$
\begin{aligned}
\text { QLPIA }_{t}= & \text { Produksi lada putih asalan } \\
& \text { Indonesia (ton) } \\
\mathrm{HLPI}_{\mathrm{t}}= & \text { Harga rill lada putih di level } \\
& \text { petani }(\mathrm{Rp} / \mathrm{kg}) \\
\mathrm{D} & =\text { Notasi pada nilai simulasi dasar } \\
\mathrm{S} & =\begin{array}{l}
\text { Notasi pada nilai simulasi } \\
\text { kebijakan }
\end{array}
\end{aligned}
$$

Sedangkan untuk menghitung surplus produsen (petani lada) yang memproduksi jenis lada putih kering dengan rumus:

$$
\begin{array}{ll}
\text { QLPIK }_{d}\left(H_{L P I}-\text { HLPI }_{d}\right)+0.5\left(\text { QLPIK }_{\mathrm{s}}-\right. \\
\text { QLPIK } \left._{\mathrm{d}}\right)\left(\mathrm{HLPI}_{\mathrm{s}}-\mathrm{HLPI}_{\mathrm{d}}\right)
\end{array}
$$

dimana:

$$
\begin{aligned}
\text { QLPIK }_{\mathrm{t}}= & \text { Produksi lada putih asalan } \\
& \text { Indonesia (ton) } \\
\text { HLPI }_{\mathrm{t}}= & \text { Harga rill lada putih di level } \\
& \text { petani }(\mathrm{Rp} / \mathrm{kg}) \\
\mathrm{d} & =\text { Notasi pada nilai simulasi dasar } \\
\mathrm{s} & =\begin{array}{l}
\text { Notasi pada nilai simulasi } \\
\text { kebijakan }
\end{array}
\end{aligned}
$$

\section{HASIL DAN PEMBAHASAN}

\section{Hasil Pendugaan Model}

Hasil pendugaan model dengan metode 2 SLS menunjukkan bahwa koefisien determinasi $\left(\mathrm{R}^{2}\right)$ berkisar antara $52 \%$ sampai $98 \%$. Hal ini berarti keragaman masing-masing peubah endogen dapat dijelaskan cukup baik oleh peubahpeubah penjelas pada masing-masing persamaan struktural. Peubah-peubah penjelas pada setiap persamaan secara bersama-sama cukup nyata menjelaskan keragaman peubah endogen, yang ditunjukkan dari nilai statistik $\mathrm{F}$ berkisar antara 2.678 hingga 172.427. Berdasarkan nilai statistik $t$, terdapat beberapa peubah penjelas tidak berpengaruh secara nyata terhadap peubah endogen.

Semua tanda parameter dugaan dalam model sesuai dengan harapan berdasarkan teori maupun logika ekonomi, kecuali dummy standar mutu pada persamaan penawaran ekspor lada putih Indonesia ke Singapura (XLPS) dan ekspor Brazilia (XLPB).

\begin{tabular}{|c|c|c|c|c|c|c|}
\hline \multirow[t]{2}{*}{ No } & \multirow[t]{2}{*}{ Peubah } & \multirow{2}{*}{$\begin{array}{c}\text { Parameter } \\
\text { Dugaan }\end{array}$} & \multirow[t]{2}{*}{ t-hitung } & \multirow{2}{*}{ Taraf Nyata } & \multicolumn{2}{|c|}{ Elastisitas Jangka } \\
\hline & & & & & Pendek & Panjang \\
\hline 1. & QLPIA & & & & & \\
\hline & INTERCEP & 1601.423330 & 0.449 & - & - & - \\
\hline & HLPI & 0.589805 & 1.335 & $\mathrm{D}$ & 0.097 & 0.180 \\
\hline & $\left(\mathrm{HLHI}_{\mathrm{t}}-\mathrm{HLHI}_{\mathrm{t}-1}\right)$ & -1.052441 & -2.438 & A & -0.174 & -0.322 \\
\hline & $\mathrm{HF}$ & -7.629064 & -1.280 & $\mathrm{E}$ & -0.060 & -0.111 \\
\hline & IRI & -26.078945 & -0.279 & - & & \\
\hline
\end{tabular}

\section{Validasi Model}

Simulasi kebijakan bertujuan untuk menganalisis dampak kebijakan dengan cara merubah nilai peubah kebijakan. Sebelum model disimulasi terlebih dahulu dilakukan validasi model untuk melihat apakah nilai dengan nilai aktual masing-masing peubah endogen (Pindyck \& Rubinfield, 1991). Adapun dalam validasi model ini dilihat berdasarkan hasil dugaan parameter dan uji statistik dan indikator RMSE, U-Theil dan koefisien determinasi $\left(\mathrm{R}^{2}\right)$ untuk semua peubah endogen. Adapun pendugaan parameter dan validasi model dijelaskan secara detail dalam Tabel 2. dan Tabel 3.

Tabel 2. Hasil Pendugaan Parameter dan Uji Statistik 


\begin{tabular}{lrrrrr}
\hline W & -0.012724 & -1.033 & - & -0.051 & -0.095 \\
CHSS & -0.834358 & -0.699 & - & -0.026 & -0.047 \\
LLPIA & 0.374719 & 3.874 & $\mathrm{~A}$ & 0.527 & 0.977 \\
(YLPIA $_{\mathrm{t}-}$ YLPIA $\left._{\mathrm{t}-1}\right)$ & 14650 & 4.181 & $\mathrm{~A}$ & 0.593 & 1.098 \\
LQLPIA $^{2}$ & 0.471427 & 3.669 & $\mathrm{~A}$ & - & -
\end{tabular}

2. XLPA

\begin{tabular}{|c|c|c|}
\hline INTERCEP & 41.532746 & 0.064 \\
\hline$\left(\mathrm{HXLPI}_{\mathrm{t}}-\mathrm{HXLPI} \mathrm{t}_{\mathrm{t}-1}\right)$ & 111.853443 & 0.912 \\
\hline$\left(\mathrm{HXLHI}_{\mathrm{t}}-\mathrm{HXLHI} \mathrm{I}_{\mathrm{t}-1}\right)$ & -97.933738 & -1.086 \\
\hline$\left(\mathrm{QLPIK}_{\mathrm{t}}-\mathrm{QLPIK} \mathrm{t}_{\mathrm{t}-1}\right)$ & 0.035612 & 1.108 \\
\hline NTRIA & 0.313241 & 0.922 \\
\hline IRI & -10.591326 & -0.430 \\
\hline DM1 & 962.928303 & 2.154 \\
\hline RXLPS & -0.119523 & -2.762 \\
\hline LXLPA & 0.827475 & 9.390 \\
\hline
\end{tabular}

$\mathrm{R}^{2}=0.8943 \quad$ F-hitung $=21.151 \quad \mathrm{DW}=2.222 \quad \mathrm{~h}=-0.694$

3. XLPJ

$\begin{array}{lrrr}\text { INTERCEP } & -4188.455966 & -1.447 & - \\ \text { HXLPI } & 214.657076 & 1.504 & \mathrm{C} \\ \text { (HXLHI } \text { HXLHI }_{\mathrm{t}-1} \text { ) } & -177.844073 & -1.763 & \mathrm{~B} \\ \text { QLPIK }^{\text {NTRIA }} \text {-NTRIA }_{\mathrm{t}-1} \text { ) } & 0.142681 & 2.236 & \mathrm{~A} \\ \text { IRI } & 0.210665 & 0.229 & - \\ \text { DM1 } & -57.258945 & -1.063 & \mathrm{~F} \\ \text { RXLPS } & 1887.155461 & 1.404 & \mathrm{D} \\ \text { LXLPJ } & -0.048259 & -0.572 & - \\ & 0.559734 & 3.666 & \mathrm{~A}\end{array}$

$\mathrm{R}^{2}=0.6054 \quad$ F-hitung $=3.835 \quad \mathrm{DW}=2.136 \quad \mathrm{~h}=-0.679$

4. XLPN

$\begin{array}{lrrrrr}\text { INTERCEP } & 1487.208317 & 0.602 & - & - & - \\ \left.\text { (HXLPI }_{\mathrm{t}}-\mathrm{HXLPI}_{\mathrm{t}-1}\right) & 76.087645 & 0.277 & - & 0.055 & 0.076 \\ \left.\text { (HXLHI }_{\mathrm{t}} \text {-HXLHI }_{\mathrm{t}-1}\right) & -139.198730 & -0.685 & - & -0.079 & -0.108 \\ \text { QLPIK } & 0.067598 & 1.237 & \mathrm{E} & 0.364 & 0.500 \\ \text { NTRIA } & 0.041800 & 0.407 & - & 0.018 & 0.025 \\ \text { IRI } & -25.021102 & -0.919 & - & -0.109 & -0.150 \\ \text { DM1 } & 1726.907126 & 0.981 & - & - & - \\ \text { RXLPS } & -0.244440 & -2.682 & \mathrm{~A} & -0.582 & -0.800 \\ \text { LXLPN } & 0.273448 & 1.384 & \mathrm{D} & - & -\end{array}$

$\mathrm{R}^{2}=0.5483 \quad$ F-hitung $=3.035 \quad \mathrm{DW}=2.273 \quad \mathrm{~h}=1.810$

5. XLPP

\begin{tabular}{|c|c|c|c|c|c|}
\hline INTERCEP & -620.901430 & -0.417 & - & - & - \\
\hline$\left(\mathrm{HXLPI}_{\mathrm{t}}-\mathrm{HXLPI} \mathrm{t}_{\mathrm{t}-1}\right)$ & 86.458842 & 0.333 & - & 0.180 & 0.430 \\
\hline$\left(\mathrm{HXLHI}_{\mathrm{t}}-\mathrm{HXLHI} \mathrm{t}_{\mathrm{t}-1}\right)$ & -107.096722 & -0.584 & - & -0.173 & -0.413 \\
\hline$\left(\mathrm{QLPIK}_{\mathrm{t}}-\mathrm{QLPIK} \mathrm{t}_{\mathrm{t}-1}\right)$ & 0.025201 & 0.322 & - & 0.388 & 0.925 \\
\hline NTRIA & 0.305907 & 0.457 & - & 0.384 & 0.917 \\
\hline IRI & -14.762540 & -0.281 & - & -0.184 & -0.440 \\
\hline DM1 & 716.871946 & 0.807 & - & - & - \\
\hline
\end{tabular}




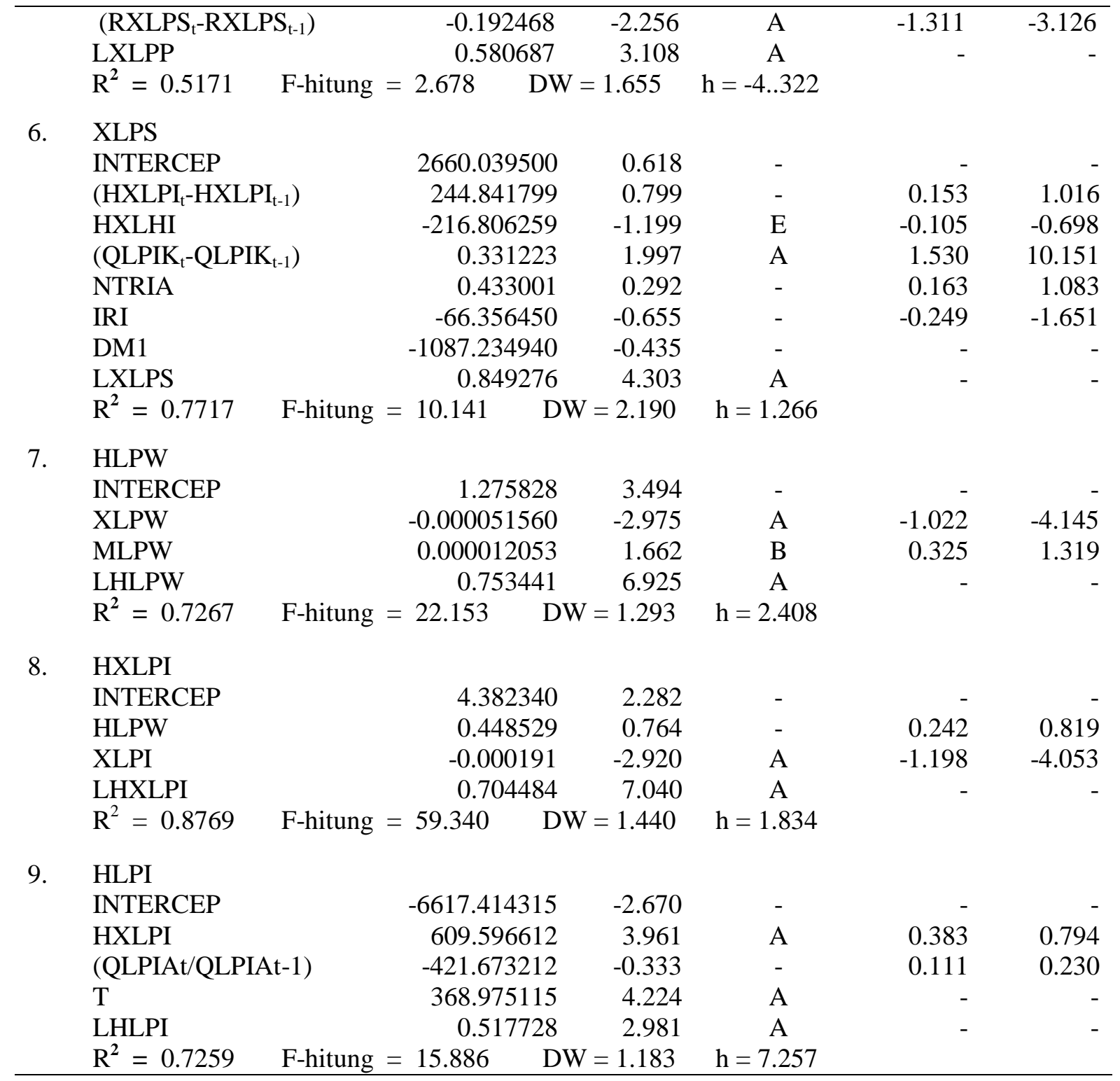

Keterangan:

$A=$ Berbeda dengan nol pada $\alpha=0.05$

$D=$ Berbeda dengan nol pada $\alpha=0.20$

$E=$ Berbeda dengan nol pada $\alpha=0.25$
Secara keseluruhan, model ini sangat baik digunakan sebagai model pendugaan. Oleh karena itu, model strukturalnya yang telah dirumuskan dan diduga dapat digunakan untuk tujuan simulasi alternatif kebijakan.

Tabel 3. Hasil Validasi Model

\begin{tabular}{cllrrr}
\hline No & \multicolumn{1}{c}{ Peubah Endogen } & RMSE & RMSPE & U Theil \\
\hline 1 & QLPIA & : Produksi Lada Putih Asalan Indonesia & 3094 & 10.8543 & 0.0635 \\
2 & QLPIK & : Produksi Lada Putih Kering Indonesia & 2946 & 10.8543 & 0.0635 \\
3 & QS & : Penawaran Lada Putih domestic & 4170 & 69.6315 & 0.3591 \\
4 & XLPA & : Ekspor Lada Putih Indonesia ke Amerika & 584.0466 & 24.6232 & 0.1392 \\
5 & XLPJ & : Ekspor Lada Putih Indonesia ke Jerman & 963.0812 & 74.1376 & 0.4060 \\
\hline
\end{tabular}




\begin{tabular}{cllrrr}
\hline 6 & XLPN & : Ekspor Lada Putih Indonesia ke Nederland & 668.6837 & 40.9197 & 0.1724 \\
7 & XLPP & : Ekspor Lada Putih Indonesia ke Jepang & 1246 & 150.9990 & 0.4004 \\
8 & XLPS & : Ekspor Lada Putih Indonesia ke Singapura & 1555 & 15.2657 & 0.0670 \\
9 & XLPI & : Total Ekspor Lada Putih Indonesia & 2682 & 14.7356 & 0.0680 \\
10 & XLPW & : Total Ekspor Lada Putih Dunia & 2682 & 9.5811 & 0.0449 \\
11 & HXLPI & : Harga Ekspor Lada Putih Indonesia & 0.1975 & 14.7273 & 0.0748 \\
12 & HLPW & : Harga Lada Putih Dunia & 0.8820 & 19.5401 & 0.1330 \\
13 & HLPI & : Harga Lada Putih di Tingkat Petani & 4546 & 30.9630 & 0.2540 \\
\hline
\end{tabular}

\section{Analisis Dampak Kebijakan}

\section{a. Dampak Kenaikan Harga Pupuk 15\%.}

Simulasi kebijakan menaikkan harga pupuk naik sebesar $15 \%$ akan menurunkan produksi lada putih asalan dan kering Indonesia masing-masing sebesar $2,495 \%$. Turunnya produksi akan direspon eksportir dengan mengurangi jumlah ekspornya secara keseluruhan sebesar 1,288\%. Menurut negara tujuan ekspor, secara persentase turunnya ekspor terbesar adalah ke Jerman (10,028\%). Namun, secara mutlak penurunan ekspornya masih lebih rendah dibandingkan ke Singapura.

Berdasarkan Tabel 4. didapatkan bahwa penurunan ekspor Indonesia tersebut akan turut menurunkan ekspor lada putih di pasar dunia sebesar $0,862 \%$, dan kemudian diikuti oleh meningkatnya harga dunia sebesar $2,371 \%$. Peningkatan harga dunia akan berdampak terhadap peningkatan harga lada putih di tingkat eksportir, importir, dan petani domesti, dimana baik secara mutlak maupun secara persentase naiknya harga ekspor Indonesia relatif lebih besar, mengingat Indonesia merupakan negara produsen dan pengekspor lada putih terbesar di pasar dunia (sekitar 60\%).

Selanjutnya, eksportir Malaysia dan Brazilia akan menaikkan volume ekspornya masingmasing sebesar $0,186 \%$ dan $0,029 \%$. Namun, disisi lain masing-masing importir negara konsumen akan mengurangi volume impornya, yaitu secara keseluruhan sebesar $0,149 \%$.

\section{b. Dampak Penurunan Suku Bunga 5\%.}

Penurunan suku bunga sebesar 5\% akan berdampak menurunkan produksi lada putih Indonesia sebesar $0,836 \%$. Kondisi ini terjadi karena dampak peningkatan produksi akibat turunnya suku bunga masih lebih rendah dari dampak penurunan harga domestik. Namun, turunnya produksi tersebut tidak menyebabkan ekspor lada putih indonesia menjadi berkurang, bahkan secara keseluruhan meningkat sebesar $5,803 \%$. Hal ini karena dampak turunnya produksi lebih rendah daripada dampak penurunan suku bunga, sehingga ekspor lada putih Indonesia masih tetap meningkat.

Penurunan harga dunia akan berdampak terhadap turunnya harga lada putih di tingkat eksportir, importir, dan petani domestik. Namun, penurunan harga ekspor terbesar terjadi pada Indonesia yaitu sebesar 20,287\%. Karena Indonesia merupakan pemasok lada putih terbesar pertama dunia, maka turunnya harga dunia akan memberikan dampak paling besar pula bagi eksportir Indonesia dibandingkan eksportir lainnya.

Tabel 4. Dampak Kebijakan Peningkatan Harga Pupuk sebesar 15\%

\begin{tabular}{lcrrrr}
\hline $\begin{array}{c}\text { Peubah } \\
\text { Endogen }\end{array}$ & Satuan & \multicolumn{1}{c}{$\begin{array}{c}\text { Nilai } \\
\text { Dasar }\end{array}$} & $\begin{array}{c}\text { Harga } \\
\text { Pupuk naik } \\
15 \%\end{array}$ & \multicolumn{2}{c}{ Perubahan } \\
\hline QLPIA & Ton & 24723.979 & 24107.932 & -616.047 & -2.492 \\
QLPIK & Ton & 23537.228 & 22950.751 & -586.477 & -2.492 \\
QS & Ton & 3026.322 & 2583.545 & -443.00 & -14.64 \\
XLPA & Ton & 1828.343 & 1824.548 & -3.795 & -0.208 \\
XLPJ & Ton & 981.544 & 883.119 & -98.426 & -10.028 \\
XLPN & Ton & 2139.988 & 2093.285 & -46.703 & -2.182 \\
\hline
\end{tabular}




\begin{tabular}{lcrrrr}
\hline XLPP & Ton & 2051.029 & 2050.440 & -0.590 & -0.029 \\
XLPS & Ton & 12394.034 & 12272.924 & -121.110 & -0.977 \\
XLPI & Ton & 21004.539 & 20733.915 & -270.624 & -1.288 \\
XLPW & Ton & 30528.818 & 30265.775 & -263.043 & -0.862 \\
HLPW & US\$ $/ \mathrm{kg}$ & 1.184 & 1.212 & 0.028 & 2.371 \\
HXLPI & US $\$ / k g$ & 2.708 & 2.838 & 0.130 & 4.804 \\
HLPI & Rp/kg & 8754.543 & 8880.706 & 126.163 & 1.441 \\
\hline
\end{tabular}

Tabel 5.Dampak Kebijakan Penurunan Suku Bunga sebesar 5\%

\begin{tabular}{ccrrrr}
\hline $\begin{array}{c}\text { Peubah } \\
\text { Endogen }\end{array}$ & Satuan & \multicolumn{1}{c}{$\begin{array}{c}\text { Nilai } \\
\text { Dasar }\end{array}$} & $\begin{array}{c}\text { Suku } \\
\text { Bunga } \\
\text { turun 5\% }\end{array}$ & \multicolumn{2}{c}{ Perubahan } \\
\hline QLPIA & Ton & 24723.979 & 24517.274 & -206.705 & -0.836 \\
QLPIK & Ton & 23537.228 & 23340.444 & -196.784 & -0.836 \\
QS & Ton & 3026.233 & 1362.321 & -1664.00 & -54.99 \\
XLPA & Ton & 1828.343 & 1899.763 & 71.420 & 3.906 \\
XLPJ & Ton & 981.544 & 1257.395 & 275.851 & 28.104 \\
XLPN & Ton & 2139.988 & 2266.966 & 126.979 & 5.934 \\
XLPP & Ton & 2051.029 & 2149.881 & 98.852 & 4.820 \\
XLPS & Ton & 12394.034 & 13039.768 & 645.734 & 5.210 \\
XLPI & Ton & 21004.539 & 22223.374 & 1218.835 & 5.803 \\
XLPW & Ton & 30528.818 & 31714.553 & 1185.735 & 3.884 \\
HLPW & US\$ $/ \mathrm{kg}$ & 1.184 & 1.065 & -0.119 & -10.062 \\
HXLPI & US\$ $/ \mathrm{kg}$ & 2.708 & 2.159 & -0.549 & -20.287 \\
HLPI & Rp/kg & 8754.543 & 8256.881 & -497.663 & -5.685 \\
\hline
\end{tabular}

Selanjutnya, petani domestik akan mengurangi produksi sebesar $0,836 \%$ akibat turunnya harga domestik sebesar 5,685\%.

Begitu juga halnya dengan eksportir Malaysia dan Brazilia akan mengurangi ekspornya masing-masing sebesar $0,812 \%$ dan $0,125 \%$ sebagai akibat turunnya harga ekspor di kedua negara ini. Disisi lain, importir pada ke lima negara konsumen akan menambah volume impornya dengan persentase yang berbeda, dimana secara keseluruhan volume impor dunia meningkat sebesar $0,616 \%$. Hal ini secara jelas dapat dilihat pada Tabel 5.

\section{c. Dampak Kenaikan Harga Pupuk 15\% dan Penurunan Suku Bunga 5\%.}

Kombinasi dari kebijakan kenaikan harga pupuk sebesar $15 \%$ dan penurunan suku bunga sebesar 5\% akan mengurangi produksi sebesar $6,668 \%$. Namun, turunnya produksi tersebut tidak menyebabkan ekspor lada putih Indonesia menjadi turun, bahkan meningkat sebesar $2,803 \%$. Hal ini dikarenakan dampak penurunan ekspor akibat kebijakan kenaikan harga pupuk dan upah masih lebih rendah dibandingkan dampak penurunan suku bunga. Sehingga kondisi ini masih tetap meningkatkan volume ekspor lada putih Indonesia.

Peningkatan volume ekspor Indonesia turut meningkatkan penawaran ekspor lada putih dunia sebesar $1,878 \%$, yang kemudian diikuti pula oleh turunnya harga dunia sebesar $4,442 \%$. Penurunan ini akan berdampak terhadap turunnya harga lada putih di tingkat eksportir, importir, dan petani domestik dengan persentase yang berbeda. Persentase penurunan harga ekspor terbesar terjadi pada Indonesia yang merupakan pemasok lada putih sekitar $60 \%$ di pasar dunia $(8,880 \%)$. Dengan meningkatnya ekspor tersebut akan memberikan dampak yang cukup berarti bagi eksportir Indonesia, apalagi fasilitas penyimpanan bagi komoditi ini belum begitu tersedia di Indonesia. Uraian ini dapat dilihat lebih jelas pada Tabel 6.

Berdasarkan dampak kebijakan yang terjadi, maka tentunya dapat dilihat bahwa dari sisi 
Tabel 6. Dampak Harga Pupuk Naik sebesar 15\% dan Penurunan Suku Bunga sebesar 5\%

\begin{tabular}{lcrrrr}
\hline $\begin{array}{c}\text { Peubah } \\
\text { Endogen }\end{array}$ & Satuan & \multicolumn{1}{c}{$\begin{array}{c}\text { Nilai } \\
\text { Dasar }\end{array}$} & $\begin{array}{c}\text { Kombinasi } \\
\text { simulasi 1 dan }\end{array}$ & \multicolumn{2}{c}{ Perubahan } \\
Unit & \% & & \\
\hline QLPIA & Ton & 24723.979 & 23075.329 & -1648.650 & -6.668 \\
QLPIK & Ton & 23537.228 & 21967.713 & -1569.515 & -6.668 \\
QS & Ton & 3026.112 & 1742.213 & -1284.00 & -42.43 \\
XLPA & Ton & 1828.343 & 1891.503 & 63.159 & 3.454 \\
XLPJ & Ton & 981.544 & 1025.690 & 44.146 & 4.498 \\
XLPN & Ton & 2139.988 & 2156.984 & 16.997 & 0.794 \\
XLPP & Ton & 2051.029 & 2148.943 & 97.914 & 4.774 \\
XLPS & Ton & 12394.034 & 12760.477 & 366.443 & 2.957 \\
XLPI & Ton & 21004.539 & 21593.198 & 588.659 & 2.803 \\
XLPW & Ton & 30528.818 & 31102.115 & 573.297 & 1.878 \\
HLPW & US $\$ / k g$ & 1.184 & 1.132 & -0.053 & -4.442 \\
HXLPI & US $\$ / k g$ & 2.708 & 2.467 & -0.240 & -8.880 \\
HLPI & Rp/kg & 8754.543 & 8558.417 & -196.126 & -2.240 \\
\hline
\end{tabular}

analisis social welfare memperlihatkan adanya keberpihakan. Apabila pemerintah berpihak kepada petani maka pilihan kebijakan yaitu menurunkan suku bunga dengan menurunkan harga pupuk. Tentu saja, kondisi ini dapat dilihat dengan adanya penurunan tingkat suku bunga kondisi ini terjadi karena dampak peningkatan produksi akibat turunnya subu bunga masih lebih rendah dari dampak penurunan harga domestik.

Namun, turunnya produksi tersebut tidak menyebabkan ekspor lada putih indonesia menjadi berkurang, bahkan secara keseluruhan meningkat. Hal ini karena dampak turunnya produksi masih jauh lebih rendah daripada penurunan suku bunga, sehingga ekspor lada putih Indonesia masih tetap meningkat.

\section{d. Dampak Simulasi Kebijakan terhadap Kesejahteraan Produsen}

Adanya kebijakan terhadap harga pupuk dan penurunan suku bunga akan berpengaruh terhadap kesejahteraan produsen di tingkat petani lada putih baik yang asalan maupun yang kering. Kedua kebijakan/non-kebijakan tersebut ini akan berpengaruh pada jumlah lada yang diproduksi lada putih asalan dan kering Indonesia dimana keduanya menurun. Demikian halnya terjadi pada jumlah lada yang diekspor pun akan terpengaruh baik berkurang ataupun bertambah. Jumlah ekspor meningkat dengan mekanisme adanya kebijakan penurunan tingkat suku bunga justru akan berdampak menurunkan produksi lada putih Indonesia.

Untuk mengetahui dampak kedua kebijakan tersebut terhadap kesejahteraan petani lada adalah dengan menghitung produsen surplus. Adapun dampak yang terjadi terhadap kesejahteraan petani lada dapat dilihat pada Tabel 7.

Berdasarkan Tabel 7. dapat dilihat bahwa kebijakan dengan naiknya harga pupuk sebesar $15 \%$, justru akan menguntungkan bagi petani lada baik petani yang memproduksi lada putih asalan maupun yang memproduksi lada putih kering. Harga pupuk yang meningkat akan menguntungkan bagi kedua petani tersebut secara berturut-turut menghasilkan Rp 3.080.390,194 ribu per tahun dan $\mathrm{Rp}$ 2.932.531,447 ribu per tahun. Apabila ditotalkan kesejahteraan yang didapatkan oleh semua petani lada sebesar Rp 6.012.922,012 ribu per tahun.

Apabila dibandingkan dengan simulasi terjadinya penurunan suku bunga sebesar 5\% ternyata surplus produsen di sektor lada di tingkat petani. Artinya, petani lada sebagai produsen penghasil lada Indonesia mendapatkan kerugian dengan adanya kebijakan tersebut. Hal ini disebabkan, besaran penurunan suku bunga tidak diimbangi oleh naiknya jumlah produksi lada, baik bagi petani penghasil lada putih asalan maupun lada putih kering. Adapun kerugian yang 


\section{Tabel 7. Dampak Harga Pupuk Naik sebesar 15\%, Penurunan Suku Bunga sebesar 5\%, dan Secara Bersama-sama pada Simulasi 1 dan 2 terhadap Surplus Produsen di Level Petani Lada Putih Asalan dan Kering}

\begin{tabular}{lcc}
\hline \multicolumn{1}{c}{ Alternatif } & \multicolumn{2}{c}{ Surplus Produsen } \\
Kebijakan & $\begin{array}{c}\text { Di Level Petani Lada } \\
\text { Putih Asalan (Rp } \\
\text { ribu/tahun) }\end{array}$ & $\begin{array}{c}\text { Di Level Petani Lada } \\
\text { Putih Kering (Rp } \\
\text { ribu/tahun) }\end{array}$ \\
\hline $\begin{array}{l}\text { Harga Pupuk Naik sebesar 15\% } \\
\begin{array}{l}\text { Penurunan Suku Bunga sebesar } \\
\text { 5\% }\end{array}\end{array}$ & 3080390,194 & 2932531,447 \\
$\begin{array}{l}\text { Harga Pupuk Naik sebesar 15\% } \\
\text { dan Penurunan Suku Bunga } \\
\text { sebesar 5\% }\end{array}$ & $-12252750,230$ & $-11664618,000$ \\
\hline
\end{tabular}

diderita oleh petani jika terjadi kebijakan ini sebesar Rp 12.252.750,230 ribu per tahun untuk petani lada putih asalan, sedangkan bagi petani lada putih kering sebesar adalah $\mathrm{Rp}$ 11.664.618,000 ribu per tahun. Dengan demikian, kebijakan ini justru akan merugikan bagi produsen lada.

Berdasarkan penjelasan ini, dapat kita lihat bahwa kebijakan kenaikan harga pupuk ternyata tidak banyak berpengaruh negatif terhadap petani lada, tetapi justru meningkatkan keuntungan yang sangat besar setiap tahunnya. Kondisi ini dapat dilihat dari mekanisme ekonomi, dimana dengan kenaikan harga lada domestik yang akan menjadikan ekspor Indonesia turun, maka turut menurunkan ekspor lada putih di pasar dunia sebesar $0,862 \%$ dan kemudian diikuti oleh meningkatnya harga dunia sebesar $2,371 \%$.

Apabila dilihat dari sisi ekonomi positif, peningkatan harga dunia akan berdampak terhadap peningkatan harga lada putih di tingkat eksportir, importir, dan petani domestik, dimana baik secara mutlak maupun secara persentase naiknya harga ekspor Indonesia relatif lebih besar, mengingat Indonesia merupakan negara produsen dan pengekspor lada putih terbesar di pasar dunia (sekitar 60\%). Dengan demikian, maka keuntungan di tingkat petani pun akan meningkat akibat adanya dampak tidak langsung dari harga lada dunia.

Dilihat dari pareto kriteria kebijakan kenaikan harga pupuk menjadi suatu kebijakan yang belum tentu layak untuk dilakukan karena belum melihat dari sisi konsumen dengan mengukur surplus konsumen, meskipun untuk produsen menguntungkan. Artinya, pareto kriteria ini memandang bahwa apabila dengan kebijakan tersebut, paling tidak satu orang diuntungkan (better off) dan tidak ada seorang pun yang dirugikan (worse off). Dengan demikian, secara empiris bahwa banyak kebijakan yang tidak akan memenuhi pareto kriteria, termasuk kebijakan yang merugikan salah satu pihak. Dalam hal ini kebijakan penurunan suku bunga yang kelihatannya berpihak terhadap produsen, ternyata dari hasil studi ini justru sebaliknya merugikan produsen.

\section{SIMPULAN}

Berdasarkan hasil analisis, dapat disimpulkan bahwa hasil pendugaan model menunjukkan bahwa koefisien determinasi $\left(\mathrm{R}^{2}\right)$ berkisar antara $52 \%$ sampai $98 \%$. Hal ini menunjukkan keragaman masing-masing peubah endogen dapat dijelaskan cukup baik oleh peubah-peubah penjelas pada masing-masing persamaan struktural. Peubahpeubah penjelas pada setiap persamaan secara bersama-sama cukup nyata menjelaskan keragaman peubah endogen, yang ditunjukkan dari nilai statistik F berkisar antara 2.678 hingga 172.427.

Kebijakan pemerintah dalam mengurangi subsidi pupuk justru akan menyebabkan meningkatnya harga pupuk naik sebesar $15 \%$ dan akan menurunkan produksi lada putih asalan dan kering masing-masing sebesar $2,495 \%$. Penurunan suku bunga sebesar $5 \%$ akan berdampak terhadap penurunan produksi lada putih Indonesia sebesar $0.836 \%$. Hal ini terjadi karena dampak pening- 
katan produksi akibat turunnya suku bunga masih lebih rendah dari dampak penurunan harga domestik. Namun, turunnya produksi tersebut tidak menyebabkan ekspor lada putih indonesia menjadi berkurang, bahkan secara keseluruhan meningkat sebesar 5,803\%.

Kombinasi antara kebijakan meningkatkan harga pupuk sebesar $15 \%$ dan penurunan suku bunga sebesar 5\% akan mengurangi produksi sebesar 6,668\%. Namun, turunnya produksi tersebut tidak menyebabkan ekspor lada putih Indonesia menjadi turun, bahkan meningkat sebesar 2,803\%. Hal ini dikarenakan dampak penurunan ekspor akibat kebijakan kenaikan harga pupuk dan upah masih lebih rendah dibandingkan dampak penurunan suku bunga.

Disamping itu, kebijakan dengan naiknya harga pupuk sebesar 15\%, justru akan menguntungkan bagi petani lada baik petani yang memproduksi lada putih asalan maupun yang memproduksi lada putih kering. Harga pupuk yang meningkat akan menguntungkan bagi kedua petani tersebut secara berturut-turut menghasilkan $\mathrm{Rp}$ 3.080.390,194 ribu per tahun dan Rp 2.932.531,447 per tahun. Apabila ditotalkan kesejahteraan yang didapatkan oleh semua petani lada sebesar $\mathrm{Rp}$ 6.012.922,012 ribu per tahun. Sedangkan untuk kebijakan yang lainnya justru merugikan produsen dengan signifikan setiap tahunnya.

Ekspor lada putih baik asalan maupun kering memiliki elastisitas paling responsif terhadap produksi. Oleh karena itu, dalam upaya peningkatan ekspor lada putih, sebaiknya pemerintah lebih menitikberatkan kebijakan pada peningkatan produksi dan produktivitas melalui kebijakan yang pro-produsen. Seiring dengan kebijakan produksi tersebut, sebaiknya pemerintah tetap menjaga variabel yang lainnya agar tetap kondusif secara ekonomi dari sisi tingkat upah, tingkat suku bunga, dan tingkat nilai tukar memberikan iklim yang kondusif bagi eksportir lada.

\section{Persantunan}

Penulis mengucapkan terima kasih terhadap Perdana Wahyu Santosa yang memberikan kritik dan saran yang konstruktif dan Asep Jumedi untuk penyutingan dan penyusunan makalah ini. Semua kesalahan dalam makalah ini adalah tanggung jawab diri kami sendiri.

\section{REFERENSI}

Arsyad, M., 2004. Dampak Kebijakan Ekonomi terhadap Produksi dan Ekspor Kakao Sulawesi Selatan. Tesis Program Pascasarjana IPB, Bogor.

Branson, W.H., and Litvack, J.M., 1981. Macroeconomic $2^{\text {nd }}$.ed Harper and Row Publisher, New York.

Caves, R.E., J.A., Frankel dan R.W., Jones, 1993. World Trade and Payments An Introduduction. Sixth Edition. Harper Collins Colege Publishers. New York.

Dinas Perkebunan Kabupaten Bangka, 1996. Luas Areal dan Produksi Lada serta Karet dalam Kabupaten Bangka Dalam Angka. 1997. Sungailiat.

Dolan, E.G., 1974. Basic Microeconomic: Principles and Reality. The Dryden Press, Illinois, USA.

Edizal, 1998. Analisis Ekonomi Lada Putih Muntok dan Daya Saing Lada Putih Indonesia di Pasar Internasional. Tesis Fakultas Pascasarjana IPB, Bogor.

Hasyim, A.I., 1986. Kedudukan Lada Indonesia di Pasar Internasional. Tesis Program Pascasarjana IPB, Bogor.

Hasyim, A.I., 1994. Analisis Ekonomi Lada Dunia dan Dampaknya Terhadap Pengembangan Lada Nasional. Disertasi Program Pascasarjana IPB, Bogor.

International Pepper Community (IPC), 1999. Annual Pepper Statistic Pepper Community Secretariat 1969-1998, Jakarta.

Intriligator, M.D., 1978. Econometric Models, Techniques, and Applications. Prentice-Hall of India Private Limited, New Delhi.

Kindleberger, C.P., and P.H., Lindert, 1982. International Economic $7^{\text {th }}$ ed. Richard D, Irwin Inc, USA.

Koutsoyiannis, A., 1977. Theory of Economic An Introductory Exposition of Econometric Method $2^{\text {nd }}$. The MacMillan Press Ltd, USA.

Sembiring, S.A., 2007. Dampak Kebijakan Harga Dasar dan Subsidi Pupuk Terhadap Kesejahteraan Konsumen dan Produsen. Tesis Program Pascasarjana IPB, Bogor.

Triana, Farida, 1998. Penawaran Ekspor Lada Putih Indonesia dan Permintaan Impor Dunia. Tesis Fakultas Pascasarjana IPB, Bogor. 